\title{
Coastal Community Development and Fisheries Resource Management Project (Co-Fish Project) in Tegal of 1998-2005 and Its Impacts on Fishing Communities
}

\author{
Ahmad Faizal Bakhtiar ${ }^{2}$, Yety Rochwulaningsih ${ }^{l}$, and Endang Susilowati \\ ${ }^{1}$ Master Program of History, Faculty of Humanities, Diponegoro University, Semarang - Indonesia \\ ${ }^{2}$ Department of History, Faculty of Humanities, Diponegoro University, Semarang - Indonesia
}

\begin{abstract}
This research examines the issue of why Co-Fish Project is important for the ecosystem in the Tegal Port area and how the project was implemented during 1998-2005 and the impacts of the project on fishing communities. It is used as a historical method with the ecosystem approach because Co-Fish Project intended to maintain, improve, and develop the benefit value and the ecosystem function for the progress of all elements or stakeholders in the ecosystem. The research results show that Co-Fish Project in Tegal City is an integral part of the Coastal Fishing Port (PPP) construction project and the development of the Tegalsari Fish Landing Base (PPI) of Tegal City. Co-Fish Project as a central government project under the coordination and management of the Indonesian Ministry of Maritime Affairs and Fisheries with ADB funding sources requires the development and empowerment of the port area ecosystem as an instrument to support the development and sustainability of port activities. It is important because the condition of the existing slum port area is not organized with the socioeconomic life of fishermen with high poverty levels and prone to conflicts among the fishermen. The implementation of the Co-Fish Project has a positive impact on reducing poverty and fishermen conflicts due to improvements in infrastructure, sanitation, and the development of fishermen's socio-economic institutions and the port area ecosystem synergizing with the increasing fishermen's income and social harmony.
\end{abstract}

Keywords: Development; Port; Fishermen; Ecosystem.

\section{Introduction}

In the initial period of reformation era, Indonesia entered a new phase in the marine and fishery sector. It was because the government made it as a development priority. Moreover, the government under President Abdurrahman Wahid formed a technical ministry to manage marine resources named Department of Marine Exploration based on Presidential Decree No.

* Corresponding author: ahmadfaizalbakhtiar@students.undip.ac.id 
136 of 1999 on November 101999 which later became the Ministry of Maritime Affairs and Fisheries and finally the Indonesian Ministry of Maritime Affairs and Fisheries. With the existence of a technical department that manages marine resources, the development program of the marine and fishery sector is increasingly massive, both with State Budget funding sources and loan or soft loan from abroad including international financial institutions such as World Bank, Asia Development Bank, etc. One of the programs is Coastal Community Development and Fisheries Resource Management Project (Co-Fish Project) with loan funds of Asia Development Bank conducted in five locations in Indonesia. For the north coast of the Java Sea, it is at Tegalsari Port, Tegal City, Central Java. There are at least two reasons in choosing the Tegalsari Port, Tegal for Co-Fish Project. First, the low quality of the port environment and the surrounding coastline which has a significant impact on the decline in the number of fishermen catch. Second, the high level of fisherman poverty living around the port area [1].

Practically, Co-Fish Project aims to create a good, healthy, and sustainable ecosystem in which the elements in the ecosystem synergize each other functionally, so as to create balance and sustainability. Therefore, Co-Fish Project technically aims to raise awareness about the importance of a healthy and clean environment, reduce social conflict caused by environmental issues such as fish waste management, marine pollution, and develop motivation to behave environmentally friendly [2]. This was important in Tegalsari, Tegal because the physical and social conditions of the community were unhealthy at that time. The environment looked dirty, the sanitation was poor and unorganized, the smell of fish waste was strong, and conflicts among the fishermen were frequently occured.

Through action programs targeting the actual and factual issues, the Co-Fish Project in Tegalsari, Tegal could be implemented well and had successfully contributed significantly in reducing the level of poverty and social conflicts among the fishermen. Different results were obtained in Bengkalis Regency for the same program and time. In Bengkalis Regency, the implementation of Co-Fish Project, was unsuccessful in improving the socio-economic conditions of the fishing community due to the lack of built infrastructure and low community participation [3]. Therefore, the successful Co-Fish Project in Tegalsari, Tegal is interesting to discuss further, how could it work and how is the project implemented and what are the socio-economic impacts felt by fishermen? These are the problem examined and discussed in this research.

\section{Research Method}

This research was a historical research. The historical criticism method was used to examine the research problems. The historical criticism method is the process of critically examining and analyzing records and relics of the past through several stages [4]. that is the heuristic stage or the collection of sources to obtain both primary and secondary data [5], internal and external criticism to obtain authenticity and credibility [6], interpretation, and historiography or critical history writing based on verified facts [7].

\section{Result and Discussion}

\subsection{Tegal Co-Fish Project}

Although Co-Fish Project was an integral part of the Coastal Fishing Port (PPP) construction project and the development of Tegal City Tegalsari Fish Landing Base (PPI), it included fishing communities and regional areas as an ecosystem. Administratively, Co-Fish Project was located in two sub-districts, namely West Tegal Sub-district and East Tegal Sub-district 
because both regions were located on the coast. In the area of West Tegal Sub-district, CoFish Project was centered in Muarareja and Tegalsari urban villages. In the area of East Tegal Sub-district, Co-Fish Project was conducted in Panggung and Mintaragen urban villages [1]. Co-Fish Project took place during 1998-2005 with loan funds from Asian Development Bank by $60 \%$ and Indonesian Government by $40 \%$. The loan number $1570 / 1571(\mathrm{SF})-\mathrm{INO}$ was valid from April 21, 1998 to December 31, 2005, as the executing agency was Directorate General of Capture Fisheries of the Ministry of Maritime Affairs and Fisheries of the Republic of Indonesia [8]. The total budget for Co-Fish Project in Indonesia for the five regions including: Bengkalis Regency, Riau Province, Trenggalek Regency, East Java Province, Banyuwangi Regency, East Java Province, East Lombok Regency, West Nusa Tenggara Province, and Tegal City, Central Java Province reached Rp. 2.166.861.381.911 and Tegal Co-Fish Project received Rp. 50,996,118,300 from the central government, while the Tegal City government provided 14 hectares of land in Tegalsari Urban Village, Tegal City [8].

The initial step in implementing Co-Fish Project in Tegal was to conduct Resource and Ecological Assessment (REA) and Social and Economic Assessment (SEA). The preparation of a fishery management plan was based on the data base elaboration results on the condition of fish resources and habitat (ecology) through the REA research as well as the socioeconomic conditions of the fishing community through the SEA research. The REA research provided information on fishery resource use and habitat conditions as well as issues that occurred in the context of fishery resource use [8].

The next activity was the development of Tegalsari Coastal Fishing Port (PPP) area with a contract value of Rp. 50,996,118300, with gradual disbursement of funds from 11 October 2002 of Rp. 15,400,002,200, continued on October 8, 2003 of Rp. 28,116,593,100, and on 9 September 2004 of Rp.7,479,505,000. With these funds, the development performed included the construction of port infrastructure and training for fishing communities.

\subsection{Coastal Fishery Resource Management (CFRM)}

In 2001, Tegal Co-Fish Project conducted four fishery resource management programs. The first was planting mangroves by 63,721 seedlings, scattered in ponds by 49,318 seedlings, 8,103 in watersheds, 6,300 seedlings in the beach, and nurseries for patchwork if there were damaged seedlings, by 42,480 seedlings [9]. The second was Artificial Coral Reef (TKB) around the waters of Karang Jeruk, of which the production and management involved stakeholder from Tegalsari, Muarareja, Kali Bacin, and Suradadi [9]. The third was Communication, Information, and Education (KIE), which were part of the coastal fishery management component with the activities performed were making pamphlet, bulletin or advertisements on radio [9]. The fourth was conflict management. Conflicts occurred because of the differences in fishing gear, for example, some fishermen from Tegalsari and Muarareja urban villages used Arad or trawl fishing gear, while the majority of fishermen used traditional fishing gear such as bag nets/trammel nets, klitik nets, kejer nets and loang nets [10]. In dealing with conflicts from the community, agreements were made involving the Village office party, community leaders, the Water and Air Police, Maritime Security Agency, Naval Base, and the formation of the Marine Fishery Management Committee (KPPL) was agreed in Tegal City [11]. The model of conflict resolution [12]. which emphasized the communication and coordination among related parties as well as the participation and accommodation of the interests of the parties, had been proven effective in which fisherman conflicts in Tegal were reduced, i.e. occurring on the average of 2 times/year.

In 2002, the development of Demersal Coral Reef in Karang Jeruk Tegal by Regional Development Institute of Kendal won the tender. The Regional Development Institute 
implementation strategy was integrated and participatory approach as well as bottom up which involved all stakeholders which were the fishermen who directly utilized the resources in Karang Jeruk waters as fishing ground [9]. Then, in 2003 Tegal Co-Fish Project City formed a Community-Based Resource Management group and a Regency/City Fisheries Resource Management Advisory Committee named District Fisheries Management Advisory Committee (DFMAC) which functioned as a platform that bridged between the community and the government as well as recommendation for the regency/city government in deciding fisheries resource management policies [13]. To facilitate the monitoring of fishing fleet, Cofish Project of Tegal City also registered boats $<30$ Gross Ton (GT) and the fishing gear used. The registration results were collected in a database system. For registered fishing boats, a special sign was attached to in the form of stickers made by the survey team [14].

In 2004, Number of Permissible Catches (JTB) was implemented as a database in the utilization of marine fishery resources. In Project Administration Memorandum (PAM) ADB point 3 on Project Components or Output for the coastal fisheries resource program, it was listed including Coastal Fishing area covered and total allowable catch determined and coastal fisheries resource management plans developed. The attachment to the decree of the Minister of Agriculture No. 995/Kpts/IK.210/9/99 on the potential of fish resources and the number of permissible catches (JTB) in Indonesian fisheries areas was also included. With the tendency of non-compliance with penalties coupled with economic pressures, there was a conflict of interest between groups of fishermen who used certain fishing gear in certain fishing areas and in certain seasons as well. In principle, according to the Code Of Conduct On Responsible Fisheries Operation, there were no prohibited fishing equipment, but only an arrangement to avoid between conflicting groups so that it was needed to be regulated regarding the prohibition of the operation of dangerous fishing gear such as Trawl which remained widely used in Tegal area, fishing lanes, arrangement of FADs installation, use of fishing gear resembling Trawl and improvement of environmental aspects [15].

\subsection{Community Development and Poverty Reduction (CDPR)}

In 2001, Tegal Co-Fish Project conducted two programs as follows: First, the demonstration of the business service improvement ability for fisherwomen carried out by NGO from the Institute for Resources and Environment Research and Development (LPPSLH) of Purwokerto. This program was conducted on September 26, 2001, at J1. Hang Tuah, Gang Arwana (by utilizing regular meetings of groups of fisherwomen) [16]. The second was assistance and guidance program for environmental sanitation management through counseling and socialization of waste and drainage control system in Tegalsari performed by the NGO of Kendal Regional Development Institute. The action was shown through the 500m-long Baal road construction due to frequent flooding, one MCK (a place for bathing, washing as well as Lavatory) was built in RT 10, and sewer repair. The waterways in RW 09 often overflowed, and the negligent of the fillet owners in handling waste caused unpleasant odors [17].

In 2003, Tegal Co-Fish Project carried out a support package program and alternative business assistance for the fisherman families. The training activities for targeted groups who received the alternative business assistance packages were divided into two batches. The first batch was conducted on October 22-23, 2003, while the second batch was on October 24-25, 2003. The training took place in Sanggar Pramuka in Tegal. The support package was carried out by an NGO, Institute for Research and Development of Development Resources of Semarang. The total number of the training participants were 80 targeted groups with the details as follows: 42 participants in batch I and 38 participants in batch II. The alternative business needs were 2,342 laying ducks, 760 laying hens, 36 ewes, and three rams [18]. 
In 2004, Tegal Co-Fish Project implemented a facilitation program for financial access to banks for fishermen in cooperation with PT. Sarana Jateng Ventura. In the first phase, Rp. 498,000,000 financial credit was distributed, covering: Rp. 48,000,000 microcredit for 20 people belonging to three groups and Rp. 450,000,000 commercial credit for three people. In phase II, Rp.477,500,000,00 was delivered, covering Rp. 365,000,000 commercial credit for six people and Rp. 112,500,000 small and medium-sized enterprises (SME) credit for 12 people who belonged to three groups. The total credit that distributed during the assistance were Rp. 975,500,000. In the next development the total credit distributed to groups of fishers were Rp. 1,702,000,000. [19].

\subsection{Fish Landing Center (FLC)}

The improvement of Fish Landing Base (PPI) environment conducted by Co-Fish Project was shown through Tegalsari PPI Building Construction in 1999, which was carried out by CV. Tri Desain who won the tender with a project value of Rp. 85,536,500. [20]. A rearrangement of the coastal area (Tegalsari Coastal Fishing Port (PPP) network and irrigation construction) was carried out in 2002, regulated by the consortium of PT Adhi Karya Branch VI and PT Hutama Karya Region V with a project value of Rp.14,000,002,000 [21]. In 2003, Tegalsari Fish Landing Base (PPI) network and irrigation construction was still regulated by the winner of the tender, the consortium of PT. SAC, PT Wijaya Karya dan PT. Teguh Raksa Jaya with the project value of Rp.21.214.891.000. [22]. The construction of port infrastructure continued in 2004, which were networks, buildings, and irrigation carried out by PT. Modern Surya Jaya as the winner of the tender with the project value of Rp.7.479.505.000. [23].

\subsection{Institutional Strengthening (IS)}

Within five years, Co-Fish Project successfully enhanced and strengthened the management of coastal fishery resources related institutions. Various groups were formed, i.e., eight groups of PSBK, District Fisheries Management Advisory Committee (DFMAC) in 4 regencies/cities: Tegal City, Tegal Regency, Brebes Regency, and Pemalang Regency. LPAC was held annually for five years with different themes. Besides, Co-Fish Project also held various training related to institutional strengthening at both community and government apparatus levels. The training included Professional Staff Training with 78 participants, three batches of Project Operational Training with 73 participants, Environmental Impact Analysis training with 15 participants, coastal zone planning and management training with 20 participants. [19].

The results obtained from the institutional strengthening programs are; first, the installation of Geographic Information System (GIS) and monitoring Controlling and Surveillance (MCS) in Tegal City Co-Fish office. The second is the staff ability in the fishery department of Tegal City, Tegal Regency, and Brebes Regency increases by 20 staff. The third is the improvement of project management skills. The fourth is the skill improvement of 223 local government staff, 12 Non-Governmental Organization (NGO) staff, and 387 community members in the field of fishery resources management and fishing communities development [24]. 


\section{Conclusion}

It could be concluded from the discussion that the Co-Fish Project implementation in Tegal can give outstanding results. The success is greatly influenced by the good support and cooperation from various parties in the implementation of the Co-Fish Project. The support and cooperation between Central Government, Central Java Provincial Government and Tegal City Government are realized through budget allocations, land facilitation, mobilization of human resources, etc. With synergy and cooperation, the Tegal Co-Fish Project is successfull in implementing four programs of which the goals are to reduce poverty levels. Before the Co-Fish Project, the poverty rate of fishers in Tegalsari reached 371 in 1998 but 178 in 2006, meaning it decreased by 108\%. There is also significant reduction in the conflicts among fishermen. Before the Co-Fish Project, there were averagely 10 cases per year and reduced to averagely 2 cases per year after the Co-Fish Project implementation.

The four Co-Fish Project Programs are First, Coastal Fisheries Resource Management (CFRM) that can be well implemented as seen from the high participation of the community. The second is Community Development and Poverty Reduction (CDPR) in the form of various direct and useful assistance, including entrepreneurship training on seafood processing. The third is the Fish Landing Center (FLC) that is delivered through port facility construction which engages several local companies. Through the adequate facilities, the fishing community is proven to be able to increase fishery production for the welfare of the fishing community of Tegalsari. The fourth is Institutional Strengthening (IS) which emphasizes more on the existing institutions and it is known among the local community. Within this context, local government and fishing communities are highly participated, bringing success in the Co-Fish Project program in Tegal.

This research is part of a thesis entitled "Perkembangan Pelabuhan Perikanan Pantai Tegalsari Kota Tegal Tahun 1998-2016" (Development of Fishing Port of Tegalsari Beach, Tegal City in 1998-2016) on History Magister Program, Faculty of Cultural Sciences, Diponegoro University.

\section{References}

1. R. Indrawasih, Ratna, et al. Pengelolaan Sumberdaya Laut Secara Terpadu (CoManagement): Evaluasi Pengelolaan Model Co-Fish, (Jakarta: Penerbit Puslit Kemasyarakatan dan Kebudayaan-LIPI, 2007).

2. Laporan Akhir Tahun Pelabuhan Perikanan Pantai Tegalsari Tahun 2006 (Dinas Kelautan Dan Perikanan Pemerintah Provinsi Jawa Tengah).

3. Repository Institut Pertanian Bogor, Pelaksanaan Co-Fish Project 1998 - 2005 di Kabupaten Bengkalis Provinsi Riau (http://repository.ipb.ac.id/handle/123456789/9401

4. L. Gottschalk, Mengerti Sejarah, terjemahan Nugroho Notosusanto (Jakarta: Universitas Indonesia Press, 1983).

5. S. Pranoto, Teori dan Metodologi Sejarah (Yogyakarta: Graha Ilmu, 2010).

6. Kuntowijoyo, Pengantar Ilmu sejarah (Yogyakarta: Yayasan Bentang Budaya,1995).

7. S. Kartodirjo, Pendekatan Ilmu Sosial dalam Metodologi Sejarah (Jakarta: Gramedia Pustaka Utama, 1992).

8. Laporan Akhir Proyek Pembangunan Masyarakat Pantai dan Pengelolaan Sumberdaya Perikanan Co-Fish Project Tegal (Jakarta: PT Trans Intra Asia, 2005).

9. Dokumen Co-Fish Project Kota Tegal, Laporan Akhir REA Tahap II CV. Bina Citra Bersama konsultan perencanaan dan pengawasan teknik (Blora: CV. Bina Citra Bersama, 2003). 
10. Direktorat Jenderal Perikanan, Analisa Survei Sosial Ekonami Perikanan Laut Tahun 1980 (Jakarta: Direktorat Jenderal Perikanan, 1982).

11. Dokumen Co-Fish Project Tegal, Laporan Akhir Magang Pengelolaan Konflik Alat Tangkap Di Lokasi Bagian Proyek, (Semarang: PT. Bumi Samudra Sejahtera, 2001).

12. I. Wahyudi, Achmad Irfan Muzni, dan Suryanto, Model Pengembangan Resolusi Konflik Nelayan Pantai Utara Jawa Timur (Gresik, Universitas Muhammadiyah, 2012).

13. Dokumen Co-Fish Project Kota Tegal, Laporan Akhir Pendampingan Pengelolaan Sumberdaya Perikanan Pantai (Semarang: LPPSP, 2003).

14. Dokumen Administrasi Co-Fish Project Tegal, Surat Perjanjian Pemborong Pekerjaan Implementasi Registrasi Kapal, (Semarang: PT. Megacitra Agung Persada Indoraya, 2003).

15. Dokumen Co-Fish Project Tegal, Laporan Akhir Studi Penentuan JTB, (Semarang: PT. Gardha Mandiri Tunggal, 2004).

16. Dokumen Co-Fish Projet Kota Tegal, Laporan Akhir Demonstrasi Peningkatan Kemampuan Pelayanan Usaha bagi Wanita Nelayan (Purwokerto: LPPSLH, 2001).

17. Dokumen Co-Fish Projet Kota Tegal, Laporan Akhir Pengelolaan Sanitasi dan Lingkungan, (Semarang: LSPD, 2002).

18. Dokumen Co-Fish Projet Kota Tegal, Laporan Akhir Paket bantuan dan Pendampingan Usaha Alternatif Keluarga Nelayan (Semarang: LPPSP, 2003).

19. Dokumen Co-Fish Project Kota Tegal, Profil Bagian Proyek Pembangunan Masyarakat Pantai dan Pengelolaan Sumberdaya Perikanan Jawa Tengah Co-Fish Project PIU Kota Tegal (Tegal: Co-Fish Project, 2004).

20. Dokumen Administrasi Co-Fish Project Tegal, Surat Perjanjian Pemborong Pekerjaan Determinasi Kebutuhan Untuk Perbaikan Infrastruktur Sosial di Kota Tegal" (Semarang: CV. Tri Desain, 1999).

21. Dokumen Administrasi Co-Fish Project Tegal, Surat Perjanjian Pemborong Pekerjaan Penataan Kawasan Pantai "Pembangunan Jaringan dan Irigasi Pelabuhan Perikanan Pantai Tegalsari” (Semarang: Konsorsorium A-HK, 2002).

22. Dokumen Administrasi Co-Fish Project Tegal, Surat Perjanjian Pemborong Pekerjaan Penataan Kawasan Pantai "Pembangunan Jaringan dan Irigasi Pelabuhan Perikanan Pantai Tegalsari” (Jakarta: Konsorsorium PT. SAC, PT. Wijaya Karya, PT. Teguh Raksa Jaya, 2003).

23. Dokumen Administrasi Co-Fish Project Tegal, Surat Perjanjian Pemborong Pekerjaan Peningkatan dan Rehabilitasi Kualitas Lingkungan Pelabuhan Perikanan Pantai Tegalsari "Jaringan, Irigasi, Gedung dan Bangunan" (Semarang: PT. Modern Surya Jaya, 2004).

24. Balitbang Kementerian Kelautan dan Perikanan. Data Ukuran Kapal Nelayan Indonesia dan Jenis Alat Tangkap (Jakarta: KKP RI, 2007). 